\title{
The effect of low dose octreotide administration on renal function and on gene expression of IGF-I axis components in experimental diabetes mellitus
}

\author{
D Rubinger, O Weiss' ${ }^{1}$, D Zarfati, M M Popovtzer and I Raz ${ }^{1}$ \\ Nephrology and Hypertension Services and 'Department of Medicine, Hadassah University Hospital, POB 12000, Jerusalem 91120, Israel \\ (Requests for offprints should be addressed to D Rubinger)
}

\begin{abstract}
The present study was undertaken to assess the chronic effects of low dose octreotide (Oc) administration in rats with experimental diabetes mellitus (DM). Metabolic and clearance studies were performed in control normal rats, in rats with streptozotocin-induced DM of 1 week duration and in similar DM rats treated with Oc, $10-20 \mu \mathrm{g} /$ day. Gene expression of IGF-I, IGF-I receptor (IGF-I R) and IGF-binding protein-1 (IGFBP-1) was examined in renal tissue from normal DM animals and DM animals treated with Oc 10, 20 and $100 \mu \mathrm{g} /$ day.

Seven days of Oc administration, $10 \mu \mathrm{g} /$ day, in rats with experimental DM, was associated with enhanced hyperglycemia, increased glomerular filtration rate and urinary sodium excretion as compared with untreated DM animals. After a higher Oc dose, $20 \mu \mathrm{g} /$ day, however, there were no significant changes in renal function and in glycemic control. Significant increases in kidney weight and kidney weight/body weight ratio were seen in DM rats as compared with control intact animals. These
\end{abstract}

changes were not affected by Oc therapy in various doses. Induction of DM was associated with a marked increase in renal IGFBP-1 mRNA expression. There were no significant changes in the expression of IGF-I or IGF-I R mRNA. Oc therapy in a low or high dose did not affect gene expression of IGF-I, IGF-I R or IGFBP-1.

Thus, the response to chronic low dose Oc administration of DM rats may vary from enhanced hyperglycemia and hyperfiltration to a lack of change in renal function or in glycemic control. Low dose Oc therapy was not associated with significant variations in renal mass or in the gene expression of IGF-I axis components.

These findings are at variance with previously published studies which show a suppressive effect of Oc on renal function and growth in experimental diabetes. This apparent discrepancy may be related to the duration of treatment or to a biphasic physiological effect of Oc when used in different doses.

Journal of Endocrinology (1998) 159, 133-140

\section{Introduction}

Diabetic nephropathy is characterized by an early increase in kidney size and function, with subsequent mesangial proliferation, extracellular matrix accumulation, albuminuria and glomerular sclerosis (Parving et al. 1996). In the last decade a significant amount of research in humans and laboratory animals has been dedicated to the role of the insulin-like growth factor-I/growth hormone (IGF-I/GH) system in the pathogenesis of diabetic renal disease. The most frequently studied animal model was streptozotocin (STZ)-induced diabetes in rats. In this model, STZ administration is associated with insulopenia, hyperglycemia, kidney enlargement and hemodynamic changes similar to those seen in insulin dependent diabetes in humans (Seyer-Hansen 1976, Jensen et al. 1981, Wald \& Popovtzer 1984). These effects could be mimicked by GH and/or IGF infusion in both human and rats (Jensen et al. 1981, Guler et al. 1988, 1989, Flyvbjerg et al. 1991).
Furthermore, infusion of IGF-I in rats with experimental diabetes mellitus (DM) was associated with enhanced renal hypertrophy (Flyvbjerg et al. 1991), suggesting that IGF-I is a major factor in these processes. A role for growth factors in the induction of renal hypertrophy and glomerulosclerosis was also shown in studies using transgenic mice (Doi et al. 1988). These animals, expressing exaggerated levels of either IGF-I or GH, display renal and glomerular hypertrophy. Transgenic mice expressing elevated GH but not IGF-I levels develop morphological lesions similar to those of diabetic glomerulosclerosis despite the absence of hyperglycemia or hypertension (Doi et al. 1988).

Induction of DM with STZ in rats is associated with a marked rise in renal IGF-I. This increase reaches a peak value $1-28 \mathrm{~h}$ after the onset of DM and precedes the increase in the kidney weight (Flyvbjerg et al. 1988, 1989). The increase of renal IGF-I tissue content in early DM is probably not the result of enhanced synthesis, since 
the expression of IGF-I mRNA usually declines 2 to 7 days after the onset of the diabetic state (Fagin et al. 1989, Flyvbjerg et al. 1990). It was therefore suggested that sequestration of IGF-I due to elevated levels of IGF-Ibinding proteins, rather than increased production, accounts for the marked kidney IGF-I accumulation in early DM (Phillip et al. 1994).

The long acting somatostatin analog, octreotide $(\mathrm{Oc})$ is a potent suppressor of $\mathrm{GH}$ secretion and has been used in DM to modulate the glycemic control via the modulation of the GH/IGF-I system and reduction of insulin resistance (Ørskov et al. 1992, Schulkes 1994). It was also shown that Oc administration is associated with a decrease in renal IGF-I content and a significant suppression of kidney growth at both short-term and long-term follow-up (Flyvbjerg et al. 1988, 1989, 1992). In these studies, however, Oc was administered in a pharmacological dose, ten times greater than that normally used in the clinical setting.

In contrast to the above findings, less consistent results were reported when Oc was administered in lower doses. In one of these studies, low dose Oc therapy (in rats with aloxan-induced diabetes) was associated with reduced kidney weight and suppressed activity of the pentose phosphate pathway as compared with untreated diabetic animals. In this investigation data on renal function were not presented (Steer et al. 1988).

In another experiment, long-term Oc administration in a low dose was studied in diabetic rats after unilateral nephrectomy. This model is usually characterized by accelerated glomerulosclerosis as compared with that seen in animals after classical STZ-induced DM. In this study Oc therapy did not affect the hemodynamic or morphological alteration associated with combined diabetes and uninephrectomy (Muntzel et al. 1992).

The present study was undertaken to reassess the chronic effects of low dose Oc administration in rats with STZ-induced DM. Metabolic and clearance studies were performed in rats with experimental DM and in normal animals. IGF-I, IGF-I receptor (IGF-I R) and insulin-like growth factor-binding protein-1 (IGFBP-1) mRNAs were examined in renal tissue from control rats, rats with STZ-induced DM and rats with DM treated with Oc.

\section{Materials and Methods}

\section{Experimental protocol}

Male rats of the Hebrew University Sabra strain weighing 200-220 g were used in all experiments. The animals were placed in individual metabolic cages with free access to tap water and standard rat chow.

Two series of investigations were performed.

The first series was the effect of Oc on renal function in rats with STZ-induced DM. These metabolic studies were performed in two subsets using two different doses of Oc.
In the First Study three groups of rats were used: (1) normal rats $(n=7),(2)$ rats with STZ-induced DM $(n=14)$, and (3) rats with STZ-induced DM treated with Oc (Sandostatin, Somatostatin analog, Sandoz) $5 \mu \mathrm{g}$ subcutaneously twice a day $(n=13)$. In the Second Study, two groups of rats were used: (1) rats with STZ-induced DM $(n=5)$, and (2) rats with STZ-induced DM treated with Oc $10 \mu \mathrm{g}$ subcutaneously twice a day $(n=7)$. The effects of Oc administration in normal rats was also studied. In this experiment, the following groups were studied: (1) normal rats $(n=12)$, and (2) normal rats treated with Oc $5 \mu \mathrm{g}$ twice a day subcutaneously.

The second series was a determination of IGF-I, IGF-I $\mathrm{R}$ and IGFBP-1 mRNA. In this series, called the Third Study, determinations of IGF-I, IGF-I R and IGFBP-1 mRNA were performed in separate experiments in control animals, rats with STZ-induced DM and rats with STZ-induced DM treated with Oc, 10 and $20 \mu \mathrm{g} /$ day (given in two subcutaneous doses as described). After initial experiments failed to show a significant effect of Oc (see results), an additional study was performed using an Oc dose of $100 \mu \mathrm{g} /$ day. Following completion of the experimental protocol, the rats were killed by aortic puncture exsanguination under ether anesthesia. The kidneys were decapsulated, and equal quadrants were immediately frozen in liquid nitrogen for RNA extraction.

Induction of DM and Oc treatment Diabetes mellitus was induced by subcutaneous injection of STZ, $55 \mathrm{mg} / \mathrm{kg}$ body weight $(\mathrm{BW})$ dissolved in citrate buffer $0.01 \mathrm{M}(\mathrm{pH}$ 4.5). Control (non-diabetic) animals were injected with citrate buffer in a volume similar to that used in diabetic rats. Treatment with Oc lasted 1 week in both subsets. Diabetic and non-diabetic rats that were not treated with Oc were injected with similar volumes of saline. Fluid and food intake, urine output, plasma and urinary creatinine, sodium, potassium and urinary albumin excretion were checked in all animals from the First and the Second Study. Plasma glucose and insulin levels were checked in all animals (First, Second and Third Studies).

At the end of all experiments kidney weight and kidney weight/BW ratio were compared in all subgroups.

\section{Insulin determination}

Plasma insulin levels were determined by RIA using human insulin as standard (Sorin Biomedica, Salluggia, Italy).

\section{Tissue $m R N A$ assay}

The assays for IGF-I, IGF-I R, and IGFBP-1 were performed by a solution hybridization-RNAse protection assay as follows. Total RNA was prepared from the renal tissue of individual rats by Tri Reagent (Molecular Research Center, Inc., Cincinnati, OH, USA) according 
Table 1 The effect of Oc administration (10 $\mu \mathrm{g}$ /day, First Study, and $20 \mu \mathrm{g} /$ day, Second Study) in rats with STZ-induced (DM). Data shown are means \pm S.E.M.

\begin{tabular}{|c|c|c|c|c|c|}
\hline & \multicolumn{3}{|l|}{ First Study } & \multicolumn{2}{|l|}{ Second Study } \\
\hline & Control $(n=7)$ & $\mathrm{DM}(n=14)$ & $\mathrm{DM}+$ Oc $10(n=13)$ & $\mathrm{DM}(n=5)$ & $\mathrm{DM}+$ Oc $20(n=7)$ \\
\hline Body weight (g) & $226 \pm 14$ & $220 \pm 8$ & $210 \pm 6$ & $209 \pm 10$ & $210 \pm 6$ \\
\hline $\mathrm{U}_{\mathrm{v}}(\mathrm{ml} / 24 \mathrm{~h})$ & $11 \pm 1$ & $48 \pm 9^{a}$ & $80 \pm 8^{a, d}$ & $49 \pm 19^{a}$ & $41 \pm 16^{\mathrm{a}}$ \\
\hline Fluid intake $(\mathrm{ml} / 24 \mathrm{~h})$ & $35 \pm 3$ & $72 \pm 11^{a}$ & $107 \pm 9^{a, d}$ & $72 \pm 24^{\mathrm{a}}$ & $65 \pm 18^{a}$ \\
\hline Food intake (g/24 h) & $23 \pm 3$ & $20 \pm 3$ & $27 \pm 3$ & $26 \pm 4$ & $24 \pm 3$ \\
\hline$P$ glucose $(\mathrm{mmol} / \mathrm{l})$ & $9 \cdot 1 \pm 0 \cdot 2$ & $25 \cdot 0 \pm 2 \cdot 7^{\mathrm{a}}$ & $31 \cdot 0 \pm 1 \cdot 6^{\mathrm{a}, \mathrm{e}}$ & $24 \cdot 8 \pm 5 \cdot 7^{a}$ & $22 \cdot 4 \pm 4 \cdot 6^{\mathrm{a}}$ \\
\hline $\mathrm{P}$ insulin $(\mathrm{mlU} / \mathrm{ml})$ & $98 \cdot 4 \pm 9 \cdot 7$ & $32 \cdot 8 \pm 5 \cdot 1^{a}$ & $57 \cdot 3 \pm 3 \cdot 2^{\mathrm{c}, \mathrm{e}}$ & $24 \cdot 9 \pm 4 \cdot 9^{a}$ & $21 \cdot 7 \pm 2 \cdot 2^{\mathrm{a}}$ \\
\hline $\mathrm{P}_{\mathrm{cr}}(\mu \mathrm{mol} / \mathrm{l})$ & $62 \cdot 8 \pm 2 \cdot 3$ & $63 \cdot 7 \pm 2 \cdot 4$ & $63 \cdot 7 \pm 1 \cdot 5$ & $70 \cdot 2 \pm 5 \cdot 6$ & $66 \cdot 7 \pm 4$ \\
\hline $\mathrm{C}_{\mathrm{cr}}(\mu \mathrm{l} / \mathrm{min} / 100 \mathrm{~g} \mathrm{BW})$ & $364 \pm 17$ & $422 \pm 31^{\mathrm{c}}$ & $517 \pm 24^{\mathrm{c}, \mathrm{e}}$ & $445 \pm 30^{\mathrm{c}}$ & $432 \pm 31^{\mathrm{c}}$ \\
\hline $\mathrm{U}_{\mathrm{Na}} \mathrm{V}(\mathrm{mEq} / 24 \mathrm{~h})$ & $1 \cdot 22 \pm 0 \cdot 01$ & $1 \cdot 58 \pm 0 \cdot 13^{b}$ & $1 \cdot 90 \pm 0.09^{\mathrm{b}, \mathrm{e}}$ & $1 \cdot 87 \pm 0.33^{c}$ & $2 \cdot 58 \pm 1 \cdot 06^{\mathrm{a}}$ \\
\hline $\mathrm{U}_{\mathrm{K}} \mathrm{V}(\mathrm{mEq} / 24 \mathrm{~h})$ & $2 \cdot 13 \pm 0 \cdot 15$ & $3 \cdot 68 \pm 0 \cdot 27^{b}$ & $4 \cdot 49 \pm 2 \cdot 4^{b}$ & $3 \cdot 46 \pm 0 \cdot 77$ & $2 \cdot 93 \pm 0.47^{c}$ \\
\hline $\mathrm{U}$ albumin $(\mathrm{mg} / 24 \mathrm{~h})$ & $5 \cdot 7 \pm 0.6$ & $15 \cdot 2 \pm 2 \cdot 4^{b}$ & $20 \cdot 4 \pm 2 \cdot 4^{b}$ & $10 \cdot 2 \pm 2 \cdot 4^{a}$ & $9 \cdot 9 \pm 3 \cdot 2^{c}$ \\
\hline Kidney weight (g) & $1.63 \pm 0.09$ & $2 \cdot 07 \pm 0.08^{b}$ & $2 \cdot 17 \pm 0 \cdot 06^{b}$ & $1 \cdot 95 \pm 0 \cdot 15^{c}$ & $1 \cdot 83 \pm 0.04^{b}$ \\
\hline Kidney weight/BW $\times 10^{3}$ & $7 \cdot 66 \pm 0.61$ & $9 \cdot 41 \pm 0 \cdot 31^{\mathrm{c}}$ & $10 \cdot 33 \pm 0 \cdot 30^{c}$ & $9 \cdot 29 \pm 0 \cdot 15^{c}$ & $8 \cdot 81 \pm 0 \cdot 21$ \\
\hline
\end{tabular}

${ }^{\mathrm{a}} P<0.0025$ vs control, ${ }^{\mathrm{b}} P<0.005$ vs control, ${ }^{\mathrm{c}} P<0.05$ vs control, ${ }^{\mathrm{d}} P<0.01$ vs $D M,{ }^{\mathrm{e}} P<0.05$ vs DM.

$\mathrm{U}_{\mathrm{v}}$, urine volume; $\mathrm{P}$, plasma; $\mathrm{C}_{\mathrm{cr}}$, creatinine; $\mathrm{U}_{\mathrm{Na}} \mathrm{V}$, urinary sodium excretion; $\mathrm{U}_{\mathrm{K}} \mathrm{V}$, urinary potassium excretion; $\mathrm{U}$ albumin, urinary albumin excretion.

to the method of Chomczynski (1993) and quantified by absorbance at $260 \mathrm{~nm}$. The integrity of the RNA and the accuracy of the spectrophotometric determinations were assessed by visual inspection of the ethidium bromidestained $28 \mathrm{~S}$ and $18 \mathrm{~S}$ ribosomal RNA bands after agarose formaldehyde gel electrophoresis of $10 \mu \mathrm{g}$ aliquots as described previously (Lowe et al. 1987b). The IGF-I, IGF-I R, and IGFBP-1 riboprobes were generous gifts from Derek LeRoith (NIH, Bethesda, MD, USA).

The antisense RNA probe used to detect IGF-I R mRNA has been previously described (Werner et al. 1989). This transcript contains 40 bases of vector sequence and 265 bases complementary to 15 bases of $5^{\prime}$ untranslated sequence and to the region encoding the signal peptide and the first 53 amino acids of the IGF-I R $\alpha$-subunit. On hybridization of this RNA probe with IGF-I R RNA and subsequent RNAase digestion, a protected band of 265 bases was obtained.

The riboprobe used to measure the levels of IGF-I mRNA was described previously (Lowe et al. 1988). This probe allows the detection of both IGF-I mRNA species encoding the IGF-Ia and IGF-Ib prohormones. Only the level of IGF-Ia mRNA, which constitutes $>90 \%$ of the total IGF-I message and correlates with the levels of IGF-Ib mRNA, was measured in this study. The IGFBP-1 mRNA was measured with an antisense probe derived from a rat IGFBP-1 cDNA clone isolated from a dexamethasone-treated H-4-11-E-C3 hepatoma cell library (G T Ooi, unpublished observations). The size of the protected band obtained by hybridizing this antisense RNA probe with IGFBP-1 mRNA was 203 bases.

The PT7 RNA 18S (Ambion, Austin, TX, USA) was used as an antisense control. The size of the protected fragment was 80 bases.
Solution hybridization-RNAase protection assays were performed as described (Lowe et al. 1987a). Briefly, $20 \mu \mathrm{g}$ of total RNA were hybridized with $1 \times 10^{6}$ d.p.m. ${ }^{32}$ P-labeled antisense RNA probes. One nanogram of total RNA was hybridized with $18 \mathrm{~S}$ antisense RNA probe. The hybridization was carried out at $45^{\circ} \mathrm{C}$ for $16 \mathrm{~h}$ in a buffer containing $80 \%$ formamide. After hybridization, RNA samples were digested with RNAase A and T1 and the protected hybrids were extracted with phenolchloroform, ethanol precipitated, and electrophoresed on $8 \%$ polyacrylamide- $8 \mathrm{M}$ urea denaturing gel. Multiple autoradiograms from each gel were scanned by a densitometer connected to a MacIntosh computer (Apple Computer Inc., Cupertino, CA, USA).

\section{Statistical evaluation}

Statistical evaluation was performed using ANOVA, an unpaired $t$-test and an unpaired $t$-test with Bonferroni correction for multiple comparison when indicated.

\section{Results}

The effect of $\mathrm{Oc}$ administration on renal function in rats with STZ-induced DM

Table 1 shows the renal and the metabolic effects of Oc administration $10 \mu \mathrm{g} /$ day (First Study) or $20 \mu \mathrm{g} /$ day (Second Study) in rats with STZ-induced DM. Several effects of Oc administration, $10 \mu \mathrm{g} /$ day, are also depicted in Fig. 1. Induction of diabetes was associated with polydypsia, polyuria and significant increase in total kidney (two kidneys) weight as compared with the control 


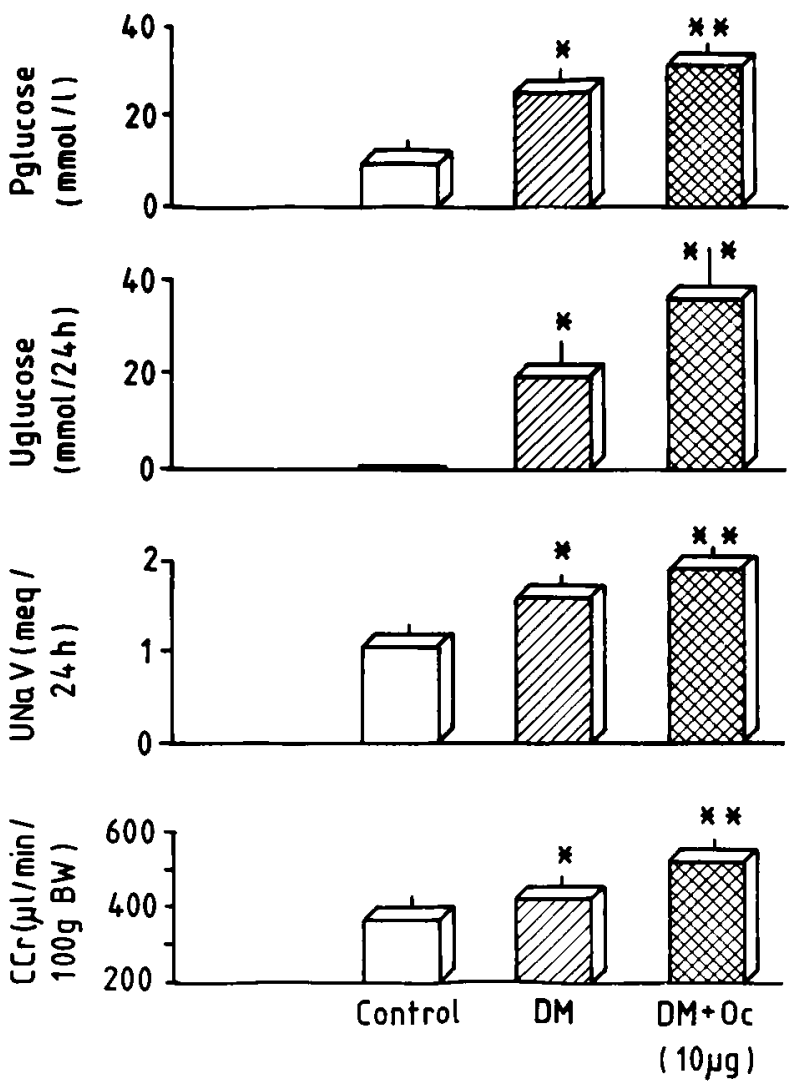

Figure 1 Creatinine clearance $(\mu \mathrm{l} / \mathrm{min}$ per $100 \mathrm{~g}$ BW), urinary sodium and glucose excretion and plasma glucose in control rats, in rats with DM and with DM treated with Oc, $10 \mu \mathrm{g} /$ day (DM+Oc). ${ }^{*}$ and ${ }^{* *}$ denote statistically significant differences vs control and DM respectively. For details, see Table 1.

animals. Polydypsia and polyuria, but not changes in kidney mass, were more prominent in rats treated with Oc. There were no significant changes in food intake between groups.

The creatinine clearance and the urinary sodium excretion were significantly increased in the diabetic rats (Table 1). These changes were more prominent in the diabetic animals treated with Oc, $10 \mu \mathrm{g} /$ day. In these animals plasma glucose and the urinary glucose excretion were higher than in the untreated DM rats. Plasma insulin levels were $98.4 \pm 9.7 \mathrm{mIU} / \mathrm{ml}$ in controls. In the First Study they were $32 \cdot 8 \pm 5 \cdot 1 \mathrm{mIU} / \mathrm{ml}$ in $\mathrm{DM}$ rats and $57 \cdot 5 \pm 3.2 \mathrm{mIU} / \mathrm{ml}$ in animals treated with Oc, $10 \mu \mathrm{g} /$ day $(P<0.0025$ and 0.05 vs control). In the Second Study they were $24.8 \pm 5.7 \mathrm{mIU} / \mathrm{ml}$ in $\mathrm{DM}$ and $22.4 \pm$ $4.6 \mathrm{mIU} / \mathrm{ml}$ in animals treated with Oc, $20 \mu \mathrm{g} /$ day $(P<0 \cdot 0025$ vs control $)$.

No significant differences in plasma creatinine, sodium and potassium were seen between groups. DM was associated with enhanced potassium excretion, more prominently in rats treated with Oc, and with albu-
Table 2 The effect of low dose Oc administration ( $5 \mu \mathrm{g} \times 2$ /day) in normal rats. Data shown are means \pm S.E.M.
Body weight (g) $\mathrm{U}_{\mathrm{v}}(\mathrm{ml} / 24 \mathrm{~h})$ Total kidney weight $(\mathrm{g})$ $P$ glucose $(\mathrm{mmol} / \mathrm{l})$ U glucose $(\mathrm{mmol} / 24 \mathrm{~h})$ $\mathrm{P}_{\mathrm{cr}}(\mu \mathrm{mol} / \mathrm{l})$ $\mathrm{C}_{\mathrm{cr}}(\mu \mathrm{l} / \mathrm{min} / 100 \mathrm{~g} \mathrm{BW})$ $\mathrm{U}_{\mathrm{Na}} \mathrm{V}(\mathrm{mEq} / 24 \mathrm{~h})$ $\mathrm{U}_{\mathrm{K}} \mathrm{V}(\mathrm{mEq} / 24 \mathrm{~h})$

a $P<0 \cdot 05$ vs control For abbreviations, see Table 1 Food intake $(\mathrm{g} / 24 \mathrm{~h})$

\begin{tabular}{|c|c|}
\hline $\begin{array}{l}\text { Control } \\
(n=12)\end{array}$ & $\begin{array}{l}\text { Oc } \\
(n=13)\end{array}$ \\
\hline $229 \pm 6 \cdot 9$ & $228 \pm 2 \cdot 1$ \\
\hline $21 \pm 1 \cdot 05$ & $17 \cdot 5 \pm 0 \cdot 77^{a}$ \\
\hline $14 \cdot 00 \pm 1 \cdot 40$ & $12 \cdot 15 \pm 1 \cdot 91$ \\
\hline $2 \cdot 11 \pm 0 \cdot 07$ & $2 \cdot 11 \pm 0 \cdot 04$ \\
\hline $7 \cdot 66 \pm 0 \cdot 24$ & $8 \cdot 31 \pm 0 \cdot 29$ \\
\hline $8.97 \pm 0.91$ & $8 \cdot 36 \pm 0 \cdot 78$ \\
\hline $54 \cdot 76 \pm 1 \cdot 39$ & $50 \cdot 88 \pm 0 \cdot 82^{a}$ \\
\hline $454 \pm 11$ & $453 \pm 19$ \\
\hline $1 \cdot 132 \pm 0 \cdot 120$ & $1 \cdot 201 \pm 0 \cdot 064$ \\
\hline $2 \cdot 612 \pm 0 \cdot 085$ & $2 \cdot 320 \pm 0 \cdot 125$ \\
\hline
\end{tabular}

minuria. There was no significant difference in urinary albumin excretion between untreated diabetic rats and those treated with Oc (Table 1).

The renal function tests were similar in untreated rats with STZ-induced DM and DM rats treated with a higher dose of Oc, $20 \mu \mathrm{g} / \mathrm{day}$ (Second Study). There were no differences between these two groups with regard to BW, plasma glucose, food and fluid intake (Table 1).

It is worthwhile mentioning that kidney weight and kidney weight/BW ratio, significantly elevated in diabetic animals, were not affected by Oc therapy in high or low doses (Table 1).

Table 2 shows the effect of low dose $(10 \mu \mathrm{g} /$ day $)$ Oc administration in normal animals. Oc therapy was associated with a mild decrease in food intake without significant changes in $\mathrm{BW}$, renal function or kidney weight.

The effect of $O c$ administration on IGF-I, IGF-I R and IGFBP-1 gene expression in renal tissue (the Third Study)

Oc administration had no effect on renal IGF-I, IGF-I R or IGFBP-1 mRNA in normal rats (data not shown).

Figures 2 and 3 depict IGF-I, IGF-I R and IGFBP-1 in control animals, rats with experimental DM and diabetic animals treated with Oc $10 \mu \mathrm{g} /$ day. Figures 4 and 5 depict IGF-I, IGF-I R and IGFBP-1 in control animals, rats with experimental DM and diabetic animals treated with Oc, 20 and $100 \mu \mathrm{g} / \mathrm{day}$. The highest dose of Oc was administered after initial studies using 10 and $20 \mu \mathrm{g} /$ day doses failed to disclose significant effects. Induction of diabetes (1 week duration) was not associated with significant changes in IGF-I or IGF-I R gene expression (Figs 2 and 4). IGFBP-1 was significantly increased in DM animals, but was not affected by Oc administration (Figs 3 and 5). IGF-I or IGF-I R gene expression were not effected by Oc in high or low doses. 


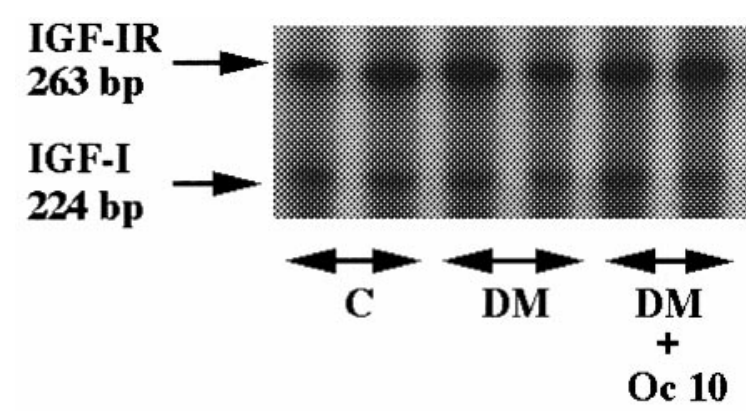

Figure 2 The effect of Oc on IGF-I and IGF-I R gene expression in control rats $(\mathrm{C})$, in $\mathrm{DM}$ rats and $\mathrm{DM}$ rats treated with Oc $(10 \mu \mathrm{g} /$ day). IGF-I and IGF-I R mRNA were measured by the solution hybridization-RNAase protection assay as described in Materials and Methods. Densitometric analysis did not show significant differences between groups.

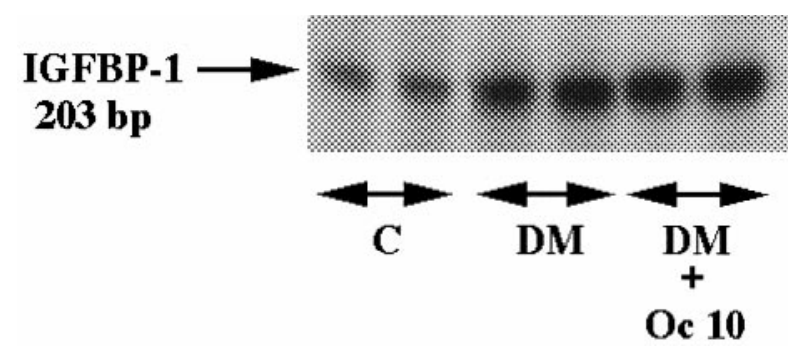

Figure 3 The effect of Oc on IGFBP-1 gene expression in control rats $(C), D M$ rats and in DM rats treated with Oc $(10 \mu \mathrm{g} /$ day $)$. Renal levels of IGFBP-1 mRNA were measured by the solution hybridization RNAase protection assay as described in Materials and Methods. Densitometric analysis showed that IGFBP-1 mRNA expression increased, in DM to $179 \pm 32 \%$ and in DM+Oc 10 to $200 \pm 32 \%$ of control values ( $P<0.05$ vs control). There were no statistically significant differences between untreated and treated DM animals.

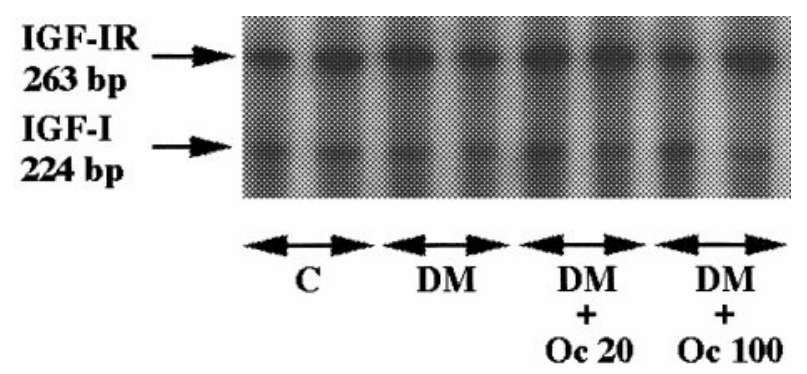

Figure 4 The effect of Oc on IGF-I and IGF-I R gene expression in control rats $(\mathrm{C})$, in DM rats and in DM rats treated with Oc (20 or $100 \mu \mathrm{g} /$ day). Renal levels of IGF-I and IGF-I R mRNA were measured by the solution hybridization RNAase protection assay as described in Materials and Methods. Densitometric analysis showed no significant differences between groups.

There were no significant differences in plasma glucose, insulin levels, kidney weight or kidney weight/BW ratio in DM rats treated with Oc 20 or $100 \mu \mathrm{g} /$ day as compared with untreated DM animals.

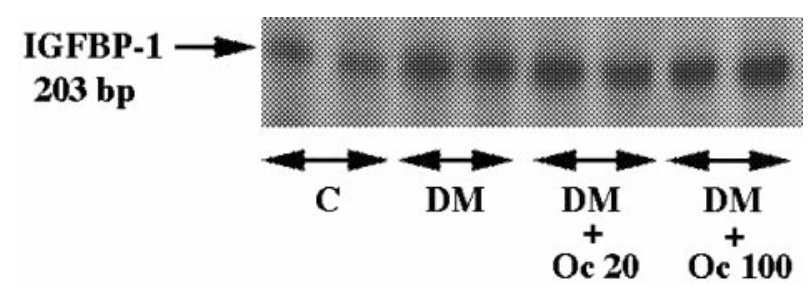

Figure 5 The effect of Oc on IGFBP-1 gene expression in control rats, in DM rats and in DM rats treated with Oc (20 or $100 \mu \mathrm{g} /$ day). Renal levels of IGFBP-1 mRNA were measured by the solution hybridization RNAase protection assay as described in Materials and Methods. Densitometric analysis showed that IGFBP-1 mRNA expression in DM animals increased to $149 \pm 13 \%$, in DM+Oc 20 to $182 \pm 32 \%$ and in DM+Oc 100 to $170 \pm 6 \%$ of controls ( $P<0.05$ vs control). There were no statistically significant differences between untreated and Oc-treated animals.

\section{Discussion}

Our study shows that in rats with STZ-induced DM, Oc administration in a dose similar to that used in a clinical setting $(10 \mu \mathrm{g} /$ day $)$ is associated with enhanced hyperglycemia, increased glomerular filtration rate (GFR) and enhanced natriuresis as compared with untreated DM animals. Paradoxically the insulin levels, markedly diminished by the diabetic state, were higher in rats treated with Oc, $10 \mu \mathrm{g} /$ day, than in the untreated rats.

After a higher dose of Oc administration $(20 \mu \mathrm{g} /$ day $)$ there were no significant changes in the renal function, kidney weight or the glycemic control. No significant effects were noted in normal animals treated with Oc.

Examination of the IGF-I axis components showed an increased expression of IGFBP-1 mRNA in renal tissue of DM animals. There were no significant changes in IGF-I or IGF-I R mRNA expression. These findings were not affected by Oc therapy, in low or high doses.

Since the early reports of the high IGF-I content found in the renal tissue of rats with experimental DM, many studies, short and long term, have been designed to assess the effect of somatostatin or its analog Oc, a potent suppresser of the GH/IGF-I system, on kidney function and mass in the diabetic state.

While it is generally accepted that Oc may diminish the insulin requirements and may improve the metabolic control in DM, its renal effects in DM with regard to increased GFR and renal size are controversial. These effects seem to be dependent on the magnitude of Oc dose, the duration of DM and the timing of the initiation of therapy relative to the duration of diabetes.

Flyvbjerg and others (Groenbaek et al. 1995a,b, Flyvbjerg et al. 1992), showed that Oc administration $(200 \mu \mathrm{g} /$ day $)$ in rats with STZ-induced DM is associated with a significant suppression of kidney growth at both short- and long-term follow-up, especially following early intervention, i.e. 3 days or less of a diabetic state. Oc 
administration in established diabetic nephropathy was unable to suppress the increase in the renal and glomerular volume or urinary albumin excretion (Groenbaek et al. 1995a,b).

In contrast, in a model of accelerated glomerulosclerosis combining experimental diabetes with unilateral nephropathy, chronic Oc therapy did not affect glomerular hyperfiltration, urinary protein excretion or renal histological changes associated with diabetes. In that study Oc was administered in a dose similar to that used for long-term therapy in clinical settings $(30 \mu \mathrm{g} / \mathrm{rat}$ ) (Muntzel et al. 1992).

Controversial data on the renal effects of Oc emerge also from clinical studies performed in diabetic patients. In patients with insulin-dependent diabetes mellitus treated with Oc $(300 \mu \mathrm{g} /$ day $)$, decreases in GFR and kidney volume, assessed by high resolution computed tomography, were found after 12 weeks of therapy (Serri et al. 1991). By contrast, in another study, no statistically significant changes were noted in GFR after somatostatin analog administration (Krempf et al. 1990).

A possible mechanism of action of $\mathrm{Oc}$ in diabetic nephropathy implies a direct action of the analog on IGF-I axis components. Thus it was speculated that the effect of somatostatin and its analogs is related to reduction of serum concentration of free IGF-I through stimulation of IGFBP-1 release into the circulation following Oc administration, as shown in normal and acromegalic patients (Ezzat et al. 1991, Serri et al. 1991, Fredstorp et al. 1994, Ørskov et al. 1994).

In a preliminary study from our laboratory (Rubinger et al. 1994), however, Oc administration in a pharmacological dose $(200 \mu \mathrm{g} /$ day $)$ in early $(48 \mathrm{~h}) \mathrm{DM}$ was associated with suppressed IGFBP-1 mRNA in both the cortex and the medulla as compared with untreated diabetic animals, but had no effect, however, on the renal function or on the renal mass.

In the present study performed on whole kidney tissue, the diabetic state (1 week duration) was not associated with significant changes in whole kidney IGF-I or IGF-I $\mathrm{R}$ mRNA while renal IGFBP-1 mRNA expression was enhanced. The finding regarding the unchanged IGF-I mRNA expression in DM rats relative to control animals is apparently at variance with other published studies in which a decreased expression was found. It is worthwhile mentioning, however, that IGF-I mRNA was found to be decreased in only $50 \%$ of kidneys in early diabetes, and was most prominent in the outer strip of outer medulla (Landau et al. 1995). Determination of IGF-I mRNA in the whole kidney tissue in a relatively early stage of DM as performed in our study could have failed to reveal more subtle variations in gene expression.

In our study, the lack of significant modifications in the IGF-I axis component gene expression following Oc therapy parallels the relative stability of renal function and renal mass. Actually, after the lowest dose of Oc, increased creatinine clearance and more pronounced hyperglycemia, but no significant change in renal weight, were noted as compared with untreated DM or DM animals treated with higher Oc doses. After Oc administration in a very low dose insulin levels were also higher than those in untreated DM. Similar findings described previously in diabetic patients, in which plasma insulin was increased, were explained by a pharmacokinetic effect, i.e. a decreased selective blood flow with diminished access of insulin to its degradation sites (liver and kidney) and subsequently reduced metabolic clearance of insulin by somatostatin (Ipp et al. 1987, Kollind et al. 1990). These effects of Oc were not reproduced in our study by higher doses of the analog.

Our findings regarding the lack of effect of low dose Oc on renal function are similar to those reported by Muntzel et al. (1992) in their uninephrectomized diabetic rats treated with low dose Oc. In that study, Oc had no influence on renal hemodynamics and actually even increased the GFR value, when this parameter was normalized for kidney weight.

The apparent discrepancy between our findings and those showing a suppressive effect of $\mathrm{Oc}$ on renal function and growth in diabetes is not completely understood, and it may be related to the low dose used by us in contrast to the pharmacological doses used by other investigators, or to the duration of treatment. Furthermore, since the various actions of somatostatin and its analogs are mediated through five specific membrane receptors with unique tissue distributions, ligand binding properties and probably different signal transduction pathways (Lamberts et al. 1996, Patel et al. 1996), administration of Oc in various doses may be associated with different receptor binding patterns and with different physiological effects.

It is worthwhile mentioning that biphasic or apparently contradictory effects of somatostatin or its analogs have already been described in several tissue lines and clinical settings. Thus, in thyroid follicular cells, somatostatin in low doses inhibits basic and IGF-I-stimulated thyroidstimulating hormone synthesis and cell proliferation, but has no effect when used in higher doses (Tsuzaki \& Moses 1990). In cultured hepatocytes, Oc at low but not high concentrations inhibits IGF-I mRNA expression (Serri et al. 1992).

It is well known that patients with somatostatinoma and high plasma levels of somatostatin may present with a whole spectrum of disturbances in glucose metabolism, from mild hypoglycemia to overt diabetes and ketoacidosis, as a result of different kinds of imbalance between suppressory effects on insulin, glucose and GH secretion (Wilding et al. 1996).

One possible way to understand the biphasic effects of somatostatin and its analogs will require investigation of their recently described immunomodulatory properties. These effects which may interfere with the endocrine activities, include inhibition of locally induced mediators 
like tumor necrosis factor (TNF) and nitric oxide (Karalis et al. 1994, Landa et al. 1995). In certain circumstances, the effect of somatostatin on the bioactivity and production of cytotoxins, especially TNF, was described to be paradoxical, i.e. enhancement of TNF activity by a lower concentration and suppressed activity in the presence of a higher concentration (Yousefi et al. 1991). Since TNF induces insulin resistance (Bazzoni \& Beutler 1996), its modulation by various doses of somatostatin or analogs may lead to an aggravation or attenuation of a pre-existing diabetic state.

These questions, however, will require further confirmation by new and extensive laboratory studies.

\section{References}

Bazzoni F \& Beutler B 1996 The tumor necrosis factor ligand and receptor families. Review article. New England Journal of Medicine 334 1717-1726.

Chomczynski P 1993 A reagent for the single-step simultaneous isolation of RNA, DNA and proteins from cell and tissue samples. Biotechniques 15 532-535.

Doi T, Striker LJ, Quaife C, Conti FG, Ralmiter R, Behringer R, Brinstek R \& Striker GE 1988 Progressive glomerulosclerosis develops in transgenic mice chronically expressing growth hormone and growth hormone releasing factor but not those expressing insulin like growth factor I. American Journal of Pathology 131 398-403.

Ezzat S, Ren SB, Graunstein GD \& Melmed S 1991 Octreotide stimulates insulin-like growth factor binding protein 1 (IGFBP1) levels in acromegaly. Journal of Clinical Endocrinology and Metabolism 73 441-443.

Fagin JA, Roberts CT Jr, Le Roith D \& Brown AT 1989 Coordinate decrease of tissue insulin-like growth factor I posttranscriptional alternative mRNA transcripts in diabetes mellitus. Diabetes $\mathbf{3 8}$ 428-438.

Flyvbjerg A, Thorlacius-Ussing O, Naeraa R, Ingerslev J \& Ørskov H 1988 Kidney tissue somatomedin C and initial renal growth in diabetic and uninephrectomized rats. Diabetologia 31 310-314.

Flyvbjerg A, Frystyk J, Thorlacius-Ussing O \& Ørskov H 1989 Somatostatin analogue administration prevents increase in kidney somatomedin $\mathrm{C}$ and initial renal growth in diabetic and uninephrectomized rats. Diabetologia 32 261-265.

Flyvbjerg A, Bornfeldt KE, Marshall SM, Arnqvist H \& Ørskov H 1990 Kidney IGF-I mRNA in initial renal hypertrophy in experimental diabetes mellitus. Diabetologia 33 334-338.

Flyvbjerg A, Bornfeldt KE, Ørskov H \& Arnqvist HJ 1991 Effect of insulin-like growth factor I infusion on renal hypertrophy in experimental diabetes mellitus in rats. Diabetologia 34 715-720.

Flyvbjerg A, Marshall SM, Frystyk J, Hansen KW, Harris AG \& Ørskov H 1992 Octreotide administration in diabetic rats: effect on renal hypertrophy and urine albumin excretion. Kidney International 41 805-812.

Fredstorp L, Werner S, Bang P \& Hall K 1994 Inverse correlation between insulin-like growth factor binding protein-1 and insulin in patients with acromegaly during treatment with the somatostatin analogue octreotide. Clinical Endocrinology 41 499-501.

Grønbaek H, Nielsen B, Frystyk J, Ørskov H \& Flyvbjerg A 1995a Effect of octreotide on experimental diabetic renal and glomerular growth: importance of early intervention. Journal of Endocrinology 147 95-102.

Grønbaek H, Nielsen B, Østerby R, Harris A, Ørskov H \& Flyvbjerg A $1995 b$ Effect of octreotide and insulin on manifest renal and glomerular hypertrophy and urinary albumin excretion in long term experimental diabetes in rats. Diabetologia 38 135-144.
Guler HP, Zapf J, Scheiwiller E \& Froesch ER 1988 Recombinant human insulin-like growth factor I stimulates growth and has distinct effects on organ size in hypophysectomized rats. Proceedings of the National Academy of Sciences of the USA 85 4889-4893.

Guler HP, Schmid C, Zapf J \& Froesch ER 1989 Effects of recombinant IGF-I on insulin secretion and renal function in normal human subjects. Proceedings of the National Academy of Sciences of the USA 86 2868-2872.

Ipp E, Sinai Y, Bar-Oz B, Nesher R \& Cerasi E 1987 Somatostatin impairs clearance of exogenous insulin in humans. Diabetes $\mathbf{3 6}$ 673-677.

Jensen PK, Sandahl-Christiansen J, Steven K \& Parving HH 1981 Renal function in streptozotocin-diabetic rats. Diabetologia 21 409-414.

Karalis K, Mastorakos G, Chrousos GP \& Tolis G 1994 Somatostatin analogues suppress the inflammatory reaction in vivo. Journal of Clinical Investigation 93 2000-2006.

Kollind M, Moberg E, Lins PE \& Adamson U 1990 Exogenous somatostatin raises plasma insulin levels in patients with insulin dependent diabetes mellitus. Hormone and Metabolic Research 22 581-583.

Krempf M, Ranganathan S, Remy JP, Charbannel B \& Guillon J 1990 Effect of long acting somatostatin analog (SMS-201-995) on high glomerular filtration rate in insulin dependent diabetic patients. International Journal of Clinical Pharmacology, Therapy and Toxicology 28 309-311.

Lamberts SWJ, van der Lely A-J, de Herder WW \& Hofland LJ 1996 Octreotide. New England Journal of Medicine 334 246-254.

Landa JI, Alvarez Sanchez J, Grau M, Sanchez JA \& Balibrea JL 1995 Somatostatin reduces the levels of tumor necrosis factor alpha in a rat model of endotoxemia induced by lipopolysaccharide. Research in Experimental Medicine 195 317-325.

Landau D, Chin E, Bondy C, Domene H, Roberts CT Jr, Grønbaek H, Flyvbjerg A \& Le Roith D 1995 Expression of insulin-like growth factor binding proteins in the rat kidney: effects of long-term diabetes. Endocrinology 36 1835-1842.

Lowe WL Jr, Roberts CT Jr, Lasky SR \& Le Roith D 1987 a Differential expression of alternative $5^{\prime}$ untranslated regions in mRNAs encoding rat insulin-like growth factor I. Proceedings of the National Academy of Sciences of the USA 84 8946-8950.

Lowe WL Jr, Schaffner AE, Roberts CT Jr \& Le Roith D $1987 b$ Developmental regulation of somatostatin gene expression in brain is region specific. Molecular Endocrinology 1 181-187.

Lowe WL Jr, Lasky SR, Le Roith D \& Roberts CT Jr 1988 Distribution and regulation of rat insulin-like growth factor I mRNA encoding alternative carboxyterminal E peptides: evidence for differential processing and regulation in liver. Molecular Endocrinology 2 526-535.

Muntzel M, Hannedouche T, Niesor R, Noel LH, Souberbielle JC, Lacour B \& Drücke TT 1992 Long term effects of a somatostatin analogue on renal hemodynamics and hypertrophy in diabetic rats. Clinical Science 83 575-581.

Ørskov H, Flyvbjerg A \& Frystyk J 1992 Octreotide and diabetes: theoretical and experimental aspects. Metabolism 41 (Suppl 2) 66-71.

Ørskov H, Wolthers T, Grøfte T, Flyvbjerg A, Vilstrup H \& Hamberg O 1994 Somatostatin stimulated insulin-like growth factor binding protein 1 release is abolished by hyperinsulinemia. Journal of Clinical Endocrinology and Metabolism 78 138-140.

Parving HH, Østerby R, Anderson PW \& Hsue WA 1996 Diabetic nephropathy. In The Kidney, ch 39, pp 1864-1892. Eds BH Brenner \& FC Rector. Philadelphia, London, Toronto, Montreal, Sydney, Tokyo: WB Saunders Co.

Patel YC, Greenwood M, Panetta R, Hukovic N, Grigorakis S, Robertson L-A \& Srikant CB 1996 Molecular biology of somatostatin receptor subtypes. Metabolism 45 31-38.

Phillip M, Werner H, Palese T, Kowarski AA, Stannard B, Bach LA, Le Roith D \& Roberts CT Jr 1994 Differential accumulation of insulin-like growth factor I in kidneys of pre- and postpubertal streptozotocin-diabetic rats. Journal of Molecular Endocrinology 12 $215-224$. 
Rubinger D, Weiss O, Nephesh I, Moshe R, Popovtzer MM \& Raz I 1994 Intrarenal insulin growth factors I (IGF-I) axis components gene expression in experimental diabetes mellitus. Journal of the American Society of Nephrology 5971.

Schulkes A 1994 Somatostatin: physiology and clinical applications. In Baillière's Clinical Endocrinology and Metabolism, vol 8, no. 1, pp 215-230. Eds P Fuller \& A Shulkes. London, Philadelphia, Sydney, Tokyo, Toronto: WB Saunders Co.

Serri O, Beauregard H, Brazeau P, Abribat T, Lambert J, Harris A \& Vachon L 1991 Somatostatin analogue, octreotide, reduces increased glomerular filtration rate and kidney size in insulin dependent diabetes. Journal of the American Medical Association 265 888-892.

Serri O, Beauregard H, Kachra Z \& Posner B 1992 Octreotide inhibits insulin-like growth factor 1 hepatic gene expression in the hypophyectomized rat: evidence for a direct and indirect mechanism of action. Endocrinology 130 1816-1821.

Seyer-Hansen K 1976 Renal hypertrophy in streptozotocin diabetic rats. Clinical Science and Molecular Medicine 51 551-553.

Steer KA, Sochor M, Kunjara S, Doepfner W \& McLean P 1988 The effect of somatostatin analogue (SMS 201-995, Sandostatin) on the concentration of phosphoribosyl pyrophosphate and the activity of the pentose phosphate pathway in the early renal hypertrophy of experimental diabetes in the rat. Biochemical Medicine and Metabolic Biology 39 226-233.
Tsuzaki S \& Moses AC 1990 Somatostatin inhibits deoxyribonucleic acid synthesis induced by both thyrotropin and insulin-like growth factor 1 in FRTL5. Endocrinology 126 3131-3138.

Wald H \& Popovtzer MM 1984 The effect of streptozotocin-induced diabetes mellitus on urinary excretion of sodium and renal $\mathrm{Na}^{+}-\mathrm{K}^{+}$-ATPase activity. Pflügers Archiv 401 97-100.

Werner H, Woloschak M, Adamo M, Shen-Orr Z, Roberts CT Jr \& Le Roith D 1989 Developmental regulation of the rat insulin-like growth factor I receptor gene. Proceedings of the National Academy of Sciences of the USA 88 7451-7455.

Wilding PH, Ghatei MA \& Bloom SR 1995 Hormones of the gastrointestinal tract. In Endocrinology, pp 2870-2894. Ed LJ De Groot. Philadelphia, London, Toronto, Montreal, Sydney, Tokyo: WB Saunders Co.

Yousefi S, Vaziri N, Carandang G, Le W, Yamamoto R, Granger G, Ocariz J \& Cesario T 1991 The paradoxical effects of somatostatin on the bioactivity and production of cytotoxins derived from human peripheral blood mononuclear cells. British Journal of Cancer $\mathbf{6 4}$ 243-246.

Received 8 July 1997

Revised manuscript received 20 February 1998 Accepted 3 June 1998 